\title{
並列計算機 PAX-128 の不定流解析への応用 \\ APPLICATION OF A PARALLEL COMPUTER, PAX-128, TO UNSTEADY FLOW ANALYSES
}

\author{
椎 貝 博 美* - 星 野 力** . 宅 敏 之*** \\ By Hiroyoshi SHI-IGAI, Tsutomu HOSHINO \\ and Toshiyuki MIYAKE
}

\begin{abstract}
The parallel array processor, or the supercomputer, will be a strong measure to handle many engineering, scientific and other problems in the near future.

PAX-128 is a computer of this category at the prototype stage with 128 microprocessors operating simultaneously which was designed and developed by the Institute of Engineering Mechanics, University of Tsukuba.

A new type of unsteady flow analysis procedure was tested by using PAX-128 and other computers. PAX-128 consumed calculation time three times more, with slightly less accurate results, than those by the present large scale computer, M200. The performance-cost ratio of $\mathrm{PAX}-128$ is about 17 times better than that of $\mathrm{M}-200$.
\end{abstract}

\section{1. 緒 言}

現在の汎用大型計算機は高速かつ大容量のものとなっ た.それにもかかわらず, 非定常の流体運動を多次元の 偏微分方程式を用いて数值的に表現するには，莫大な計 算時間を必要とする.

たとえば， $x$ 方向に 100 格子点をとれば，三次元なら ば $100^{3}$ 格子点をとらなければならない，各格子点あた り $10^{3}$ 回の四則演算を行い,さらに時間的な発展問題を 解くものとすれば, $10^{4}$ 時間ステップにわたって計算を 絽り返すことが必要となる。このとき，総演算回数は $10^{13}$ 回となる.これを 10 MFLOPS (mega floating points operations per second; 100 万回浮野小数点演算/秒) の演算速度を 持つ汎用大型計算機で計算するとしても，計算時間にお よそ 12 日, 計算費用は約 1000 万円かかってしまう ${ }^{11}$. これは, 一般のユーザーにとっては, 非現実的な值であ る.

一方, 原子力工学の分野に扔いても, 現実的な計算を 行い, 正確な数值モデルを導入するには, 現在の汎用機

* 正会員 工博 筑波大学教授 構造工学系 （宁305/茨城県新治郡桜村天王台 1-1)

** 工博 筑波大学教授 構造工学系 (同上)

*** 学生員 工修 筑波大学工学研究科 (同上)
の 1000 10000 倍の能力が必要になる ${ }^{2)}$ という.

このような背景から，偏微分方程式によって記述され る連続体あるいは場のシミュレーション専用の並列計算 機の製作が開始された.

まず 1979 年に 9 台のマイクロプロセッサーを直角格 子状に結んだ PACS-9 (PACS : Processor Array for Continuum Simulation) $)^{8}$ が完成し, ついで 1980 年には 32 台並列の PACS-324, ,5),6)が, 1983 年には 128 台並列の PAX-128 (PAX : Processor Array experiment) $)^{8)}$ が稼働し始めた.

これまでに,これらの PACS $(\mathrm{PAX})$ を用いて

(1) BWR 炉心計算8)

(2) 二次元弾性体問題の存限要素解析9

(3) アモルファス物質のシミュレーション10)

(4) プラズマ粒子モデルのシミュレーション ${ }^{11}$ などが行われてきた.

処理速度は PACS-32 では 0.5 MFLOPS, PAX-128 では 4 MFLOPS であり, ポアソン方程式の求解におい ては，大型計算機 FACOM M-200 とほぼ同じ計算速度 が得られている12).

しかし，並列計算機 PAX (あるいはPACS) が生まれて 日が浅いため, 水理学をはじめとして, 土木工学の分野 における計算応用例は皆無に等しい.

そこで筆者らはその最初の試みとして, PAX-128 を 
用いて, 河川における不定流計算を行った.

開水路の不定流計算については現在までに非常に多く の試みがある.筆者らに関係したものだけでも木下 ${ }^{13), 14)}$ による新高瀬川にを対象とした計算例をはじめとして， かねてから様々な方法で行われてきた.

たとえば吉川・椎貝 ${ }^{15)}$ は陽的解法により洪水と高潮に よる河口付近の水位変動を求め, I. Stepién ${ }^{16)}$ は陰的解 法により 4 点公式を用いて計算を行った. 同じ陰的解法 により最近行われたものとしては，建設省土木研究所が 利根川水系を対象として行った一連の計算例 ${ }^{17)}{ }^{188)}$,19) が あげられる.このほか, 伊藤ら ${ }^{20)}$ の貢献も多大である.

PAX を用いた計算を行らにあたり，筆者らが配慮し た点は次のとおりである.

現在の空間に関して一次元的な差分方程式による陰的 あるいは陽的な解法はかなり高い水準に達している.し かし，近い将来に河道内において二次元あるいは三次元 的な計算を行う必然性が存在する以上, 現況のままでは 計算機の計算速度が不足することは確かである.これは 特に陰的な計算においてそうであるが，また，陽的な差 分における計算の不安定性も無視することはできない.

これらの点を考虑して, 本研究においては風上差分を 用いた陽的な差分法を基にした計算法を用いた。

その結果, 比較的安定した解を得ることができた.

また, $384 \mathrm{~km}$ の河川における 5 時間にわたる洪水追
跡に要する時間を測定したところ，M-200 で 51.7 秒， PAX-128 で 160.7 秒であり, PAX の計算速度は大型 計算機の約 $1 / 3$ との結果が得られた.

この結果に価格を考慮し性能対価格比を計算すると， PAX-128 の性能価格比は, M-200 の約 17 倍であっ た. したがって, この観点からは大型計算機を超える能 力を $\mathrm{PAX}-128$ が持つものと判断することができる.

\section{2. 並列計算機 $\mathbf{P A X}-128^{7), 12 \text { ) }}$}

\section{(1) PAX-128 のハードウェア}

Fig. 1 に PAX-128 のシステム構成を示す. PAX128 は $8 \times 16$ の二次元值角格子状に配置された 128 台 の Processing Unit (PU), PU 群を制御する Control Unit (CU) および Host Computer (HOST) から構成され ている.

PU は並列に処理される個々のタスクを実行するマイ クロコンピューターである. 各 PU は前後左右の隣接寸 るPUとの間に通信用メモリー (CM) を持っており，こ の CM を介して各 PU が互いにデータ交換することが できる.さらに各 PU はそれぞれ固存のメモリー (LM) を持っており, 独自に自分のプログラムを実行すること も可能である.

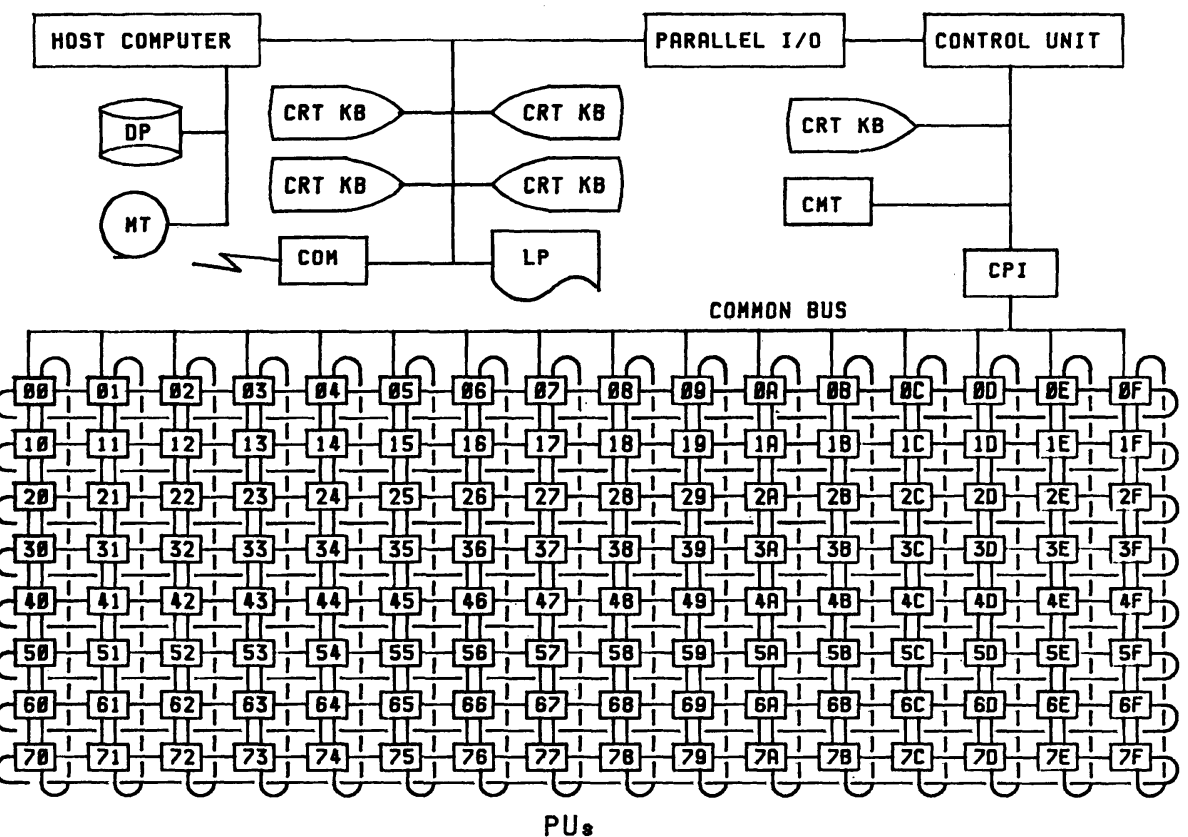

DP : DISK PACK MEMORY CRT : CATHODE RAY TUBE KB : KEY BOARD CMT : CASSETTE MAGNETIC TAPE
LP : LINE PRINTER MT : MAGNETIC TAPE CPI : CU-PU INTERFACE 
$\mathrm{CU}$ は 8 ビットのマイクロコンピューターで, HOSTPU 間のデータ転送および PU 群の制御を行う.CU は HOST とは 8 ビットパラレルインターフェイスを通じ て，また PU とは共通バスで CU-PU インターフェイ スを介して結ばれている．CU はすべての，あるいは任 意の PU へ同時に同一データ, プログラムを転送するこ とが可能である.

HOST は汎用ミニコンピューター， TI 990/20 で PAXのためのプログラムの開発, PAX ヘオブジェクト プログラムのローディング, およびデータの入出力等を 行う.

\section{(2） PAX-128 のソフトウェア}

PU のプログラムは，PAX の並列処理のために開発 された PASCAL 的な SPLM 言語6)で作成する.

一方, HOST では FORTRAN 言語でプログラムを 記述し, プログラムの開始, データの入出力, PAX のデータの転送および PU の駆動などの仕事を担当す る.

ジョブの流れを Fig. 2 に示す. すなわち，HOST コ ンピューターで, ソースプログラムを作成しコンパイル およびリンクする．HOST 用プログラムを実行すると 各 PUに SPLM のオブジェクトプログラムがロードさ れ, 並列処理が開始される. 並列処理の終了後 HOST により，PU 上から必要な変数を呼びだして出力を行 5 .

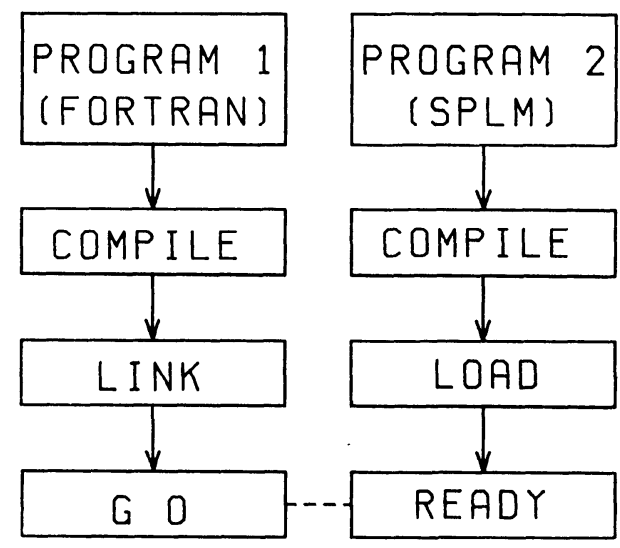

Fig. 2 Job Process

\section{3. 不定流計算}

\section{（1） 基礎方程式 ${ }^{21)}$}

不定流計算で用いる基礎式は， 連続の式 $\frac{\partial Z}{\partial t}+\frac{1}{B} \frac{\partial Q}{\partial x}=0$

および運動方程式

$\frac{\partial V}{\partial t}+g\left[\frac{\partial Z}{\partial x}+\frac{n^{2}}{R} V|V|\right]+V \frac{\partial V}{\partial x}=0$

である.

ここに,

$Z:$ 基準面からの水位

$t:$ 時間

$x:$ 上流から下流へ向けての距離

$B:$ 水路幅

$Q:$ 流量

$V: x$ 方向の平均流速

$n:$ Kutter の定数, いわゆるマニング俰数

$g:$ 重力加速度

$R:$ 動水半径

を表す。

\section{（2）差 分 化}

河村 ${ }^{22)}$ は円柱まわりの高レイノルズ流れを解析するに 際に, 計算全体として安定が保たれるように次のような 風上差分を変形した差分スキームをとった.

$$
\left(f \frac{\partial u}{\partial x}\right)_{i}=\left\{\begin{array}{c}
f_{i}\left(u_{i+2}-2 u_{i+1}+9 u_{i}-10 u_{i-1}\right. \\
\left.\quad+2 u_{i-2}\right) / 6 \Delta x, \quad\left(f_{i} \geqq 0\right) \\
f_{i}\left(-2 u_{i+2}+10 u_{i+1}-9 u\right. \\
\left.+2 u_{i-1}-u_{i-2}\right) / 6 \Delta x, \quad\left(f_{i}<0\right)
\end{array}\right.
$$

本研究ではこの差分スキームを（2）式第 4 項を差分 化する際に適用した.

その理由は，一般にこの項が $V$ に関して非線形であ るために，計算の不安定などを生じることが多いためで ある. 式 (2) 第 3 項も $V$ に関して非線形であるが, 開 水路においては摩擦の影響が小さいためこの項が問題を 起こすことは比較的少ない，もちろん，この項を無視し ても良いという意味ではない。

計算 $i$ が点まで進んだときには， $u_{i-2}, u_{i-1}$ は前の時 刻の計算加求まっている既知の值であり, $u_{i+1}, u_{i+2}$ はこれから求めようとする值である。

差分方程式を陰的に解く方法は，これら一連の $u_{i}$ の 值を連立方程式によって解くものであり，陽的に解く方 法は一度 $u_{i+1}, u_{i+2}$ に関する推定值を設定して逐次近似 法によって順次解くといった方法が用いられることが多 W.

本研究においては，できるだけ繰り返しのない簡単な 差分形で，かつ安定な方法を追及するといら見地から， この $u_{i+1}, u_{i+2}$ の值には時刻 $\Delta T$ 秒前の值を用いた.こ のようにしても計算不安定は生じなかった. 式 (2) 第 4 項以外については，同様の方針ですべて単純な後退差分 
を用いた.したがって式（1）および式（4）は，それぞ れ式（4）および式（5）のように書き直すことができ る.

$$
\begin{aligned}
& \left(Z_{i, j}-Z_{i, j-1}\right) / \Delta T+\left(Q_{i, j}-Q_{i-1, j}\right) / B \Delta X=0 \\
& \left(V_{i, j}-V_{i, j-1}\right) / \Delta T+g\left[\left(Z_{i, j}-Z_{i-1, j}\right) / \Delta X\right. \\
& \left.+n^{2} V^{2}{ }_{i, j} / R\right]+V_{i, j}\left(V_{i+2, j-1}-2 V_{i+1, j-1}\right. \\
& \left.+9 V_{i, j}-10 V_{i-1, j}+2 V_{i-2, j}\right) / 6 \Delta X=0 \text {. }
\end{aligned}
$$

\section{（3）初期条件・境界条件}

河川モデルとして矩形断面をもつ水路を考え， $t=0$ の とき水路全体にわたって等流状態を仮定し，これを初期 条件とする.

流速はマニングの公式より， $V=R^{2 / 3} \cdot I^{1 / 2} / n$

で与えられるものとする. ここに $I$ は河床勾配である.

ここで動水半径 $R$ は水深を $h$ とすると, $h / B \ll 1 の$ 場合にはよく知られているよらに

$R=h$

である.したがって流速 $V$ および流量 $Q$ はそれぞれ

$$
V=h^{2 / 3} \cdot I^{1 / 2} / n
$$

$Q=A \cdot V=B \cdot h^{5 / 3} \cdot I^{1 / 2} / n$

と表される. 水深 $h$ に対して, $n, B, I$ を与えておき 式 (8) および式 (9) より, 初期条件としての流速および 流量をまず定める.

境界条件として上流端では, 式(10)に示すように二次 関数的に洪水位を与えるものとする.

$Z=S_{0}+t(3000-t) / 1500^{2}$ (単位は $\left.\mathrm{m}, \mathrm{s}\right) \cdots \cdots(10)$

ここに

$S_{0}$ : 上流端における水路底の高さ

である.もちろん，任意の水位流量曲線も与えることは 可能である.

\section{（4） PAXによる計算方法}

本研究では Fig. 3 に示すように 128 台の PUを一 次元に配列し, 各に PU 距離方向の核子点 3 点ずつを担 当させ計算を行った.

移流項に式 (5) に示す差分法をとったため, 計算はパ イプライン型として進行する. 進行順序を具体的に,

Fig. 4 に示す.

Fig. 4 から明らかのように計算機時間ステップが 1 のとき, 計算を行う PUは 1 台だけであるが，その後計 算機時間が 1 ステップ進むたびに計算を行ら PU も 1 台 ずつ増加し, 計算機時間ステップ数が PU 台数を越える と，すべてのPUが同時に計算を行う状態となる．しか し, 残り計算機時間ステップ数が PU 台数より少なくな ると, 計算を行う PUは 1 台ずつ減少して, 計算を終了

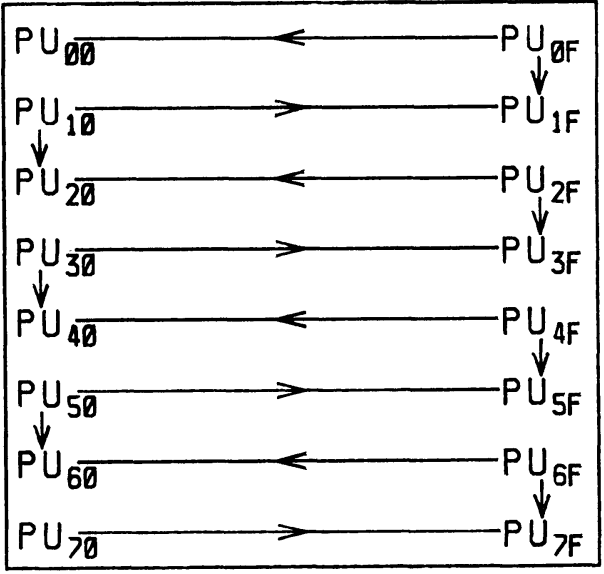

Fig. 3 Arrangement of PUs

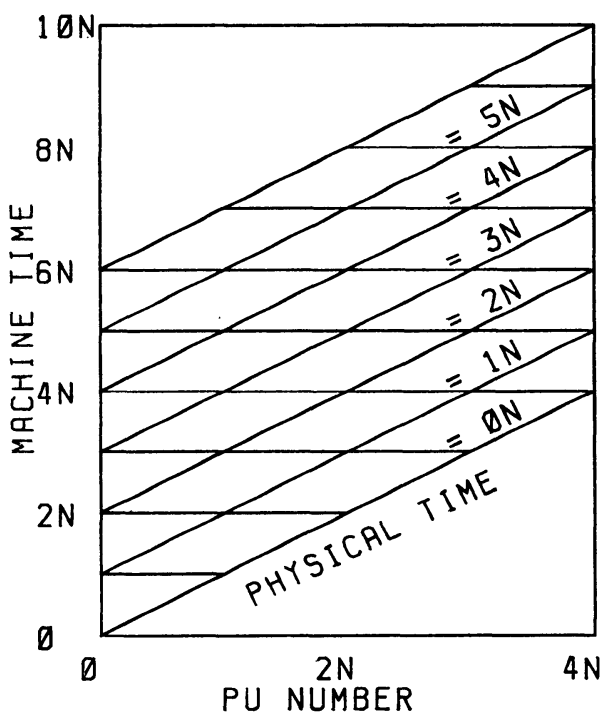

$($ Mesh Points $=$ PU Number $\times 3)$

Fig. 4 Computational Sequence

する.

また，図から PUごとに異なった物理時間を計算して いることが読み取れる.

PAX による具体的な計算手順の概要は次のとおりで ある.

(1) $1 \mathrm{PU}$ に距離方向の格子点 3 点ずつを担当させる.

(2) 全PUに初期值を与える.

(3) PU の位置に応じたデータ転送を行う．一Fig 3 に示したように PU を一次元的に連結したため に, 両端あるいは奇数行, 偶数行によってデータ転 送の向きが異なる——.

(4) ・上流端で水位の上昇を時間に対して二次関数と して与える。

・上流端，下流端以外の格子点で，連続式，運動 


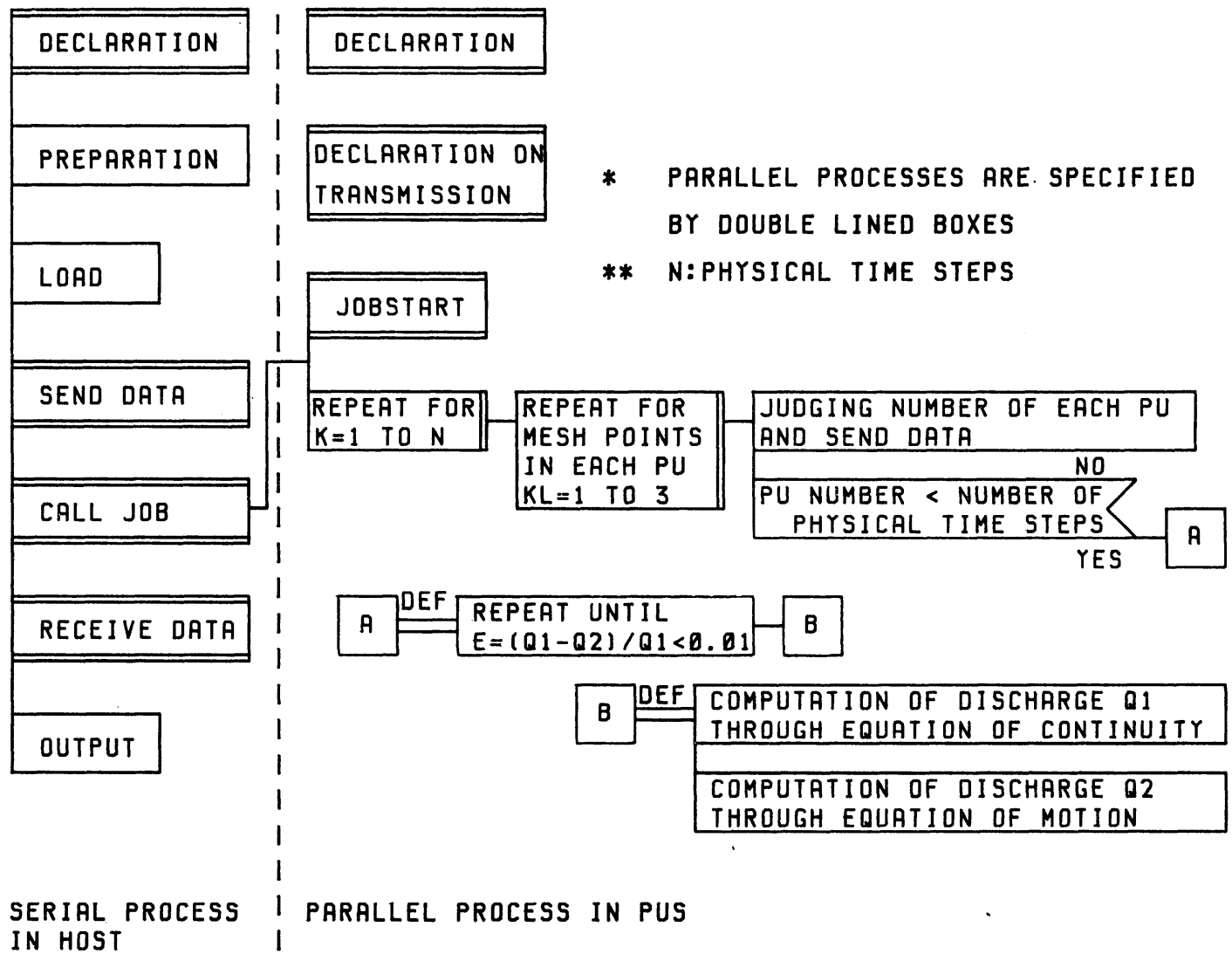

Fig. 5 PAD for Computation of Unsteady Flow by PAX-128

方程式よりそれぞれ流量 Q1 および Q2 を計 算する.

・下流端では前の 2 つの格子点における值の平均 值を与える.

(5) 流量が Q1，Q2 の誤差が 0.01 以下になるまで 計算を繰り返す.

(6) 物理時間を更新し, (3)ステップに戻る.

以上のプロセスを HOST 側のタスクも含めて Fig. 5 に, PAD (PROGRAM ANALYSIS DIAGRAM) 28),26),25) を 用いて表わす.

\section{4. 結果および考察}

まず最初に，計算に用いた差分スキームの安定性をみ るために，PC-8001 mk II を用いて計算した結果を示 す.Fig. 6 には $0 ， 5 ， 10$ および $15 \mathrm{~km}$ の各地点にお ける 5000 秒をでの水位の変動の様子を, Fig. 7 には $5 \mathrm{~km}$ 地点における， $\Delta T$ の違いによる水位変動高, Fig. 8 には $\Delta T=380$ 秒, $\Delta X=1000 \mathrm{~m}$ として, 距離 $20 \mathrm{~km}$, 時間 5320 秒まで計算した結果を示す. 以上の

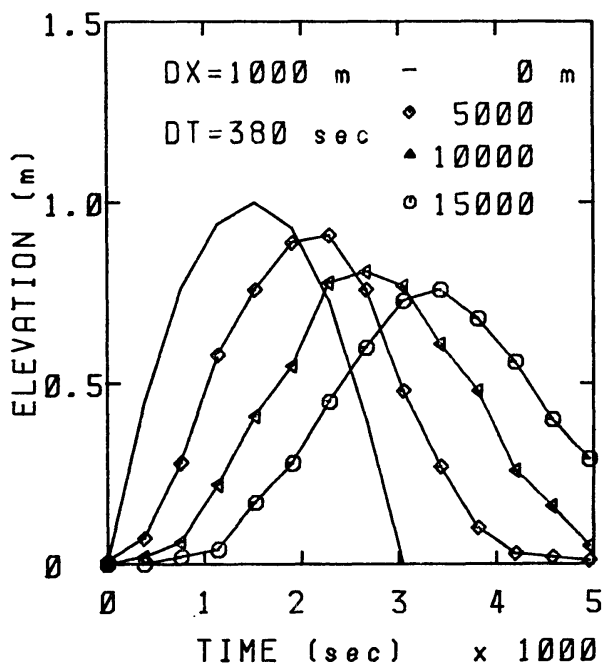

Fig. 6 Flood Wave at Each Point

結果から，本研究で用いた差分スキームは，比較的安定 な解を与えることがわかる.

また, Fig. 9 には PAX-128 による 0.10 および 20 $\mathrm{km}$ の各地点における水位変動高の変化を三次元的に示 した. 


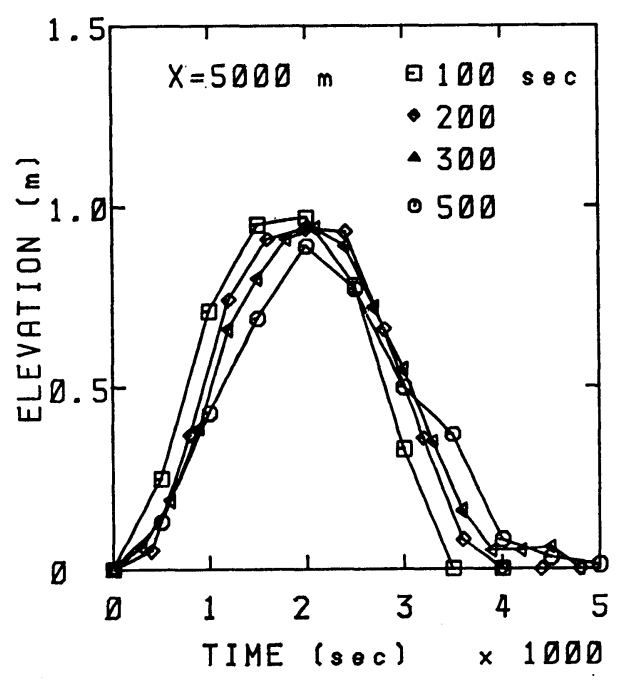

Fig. 1 Influence of Time Step

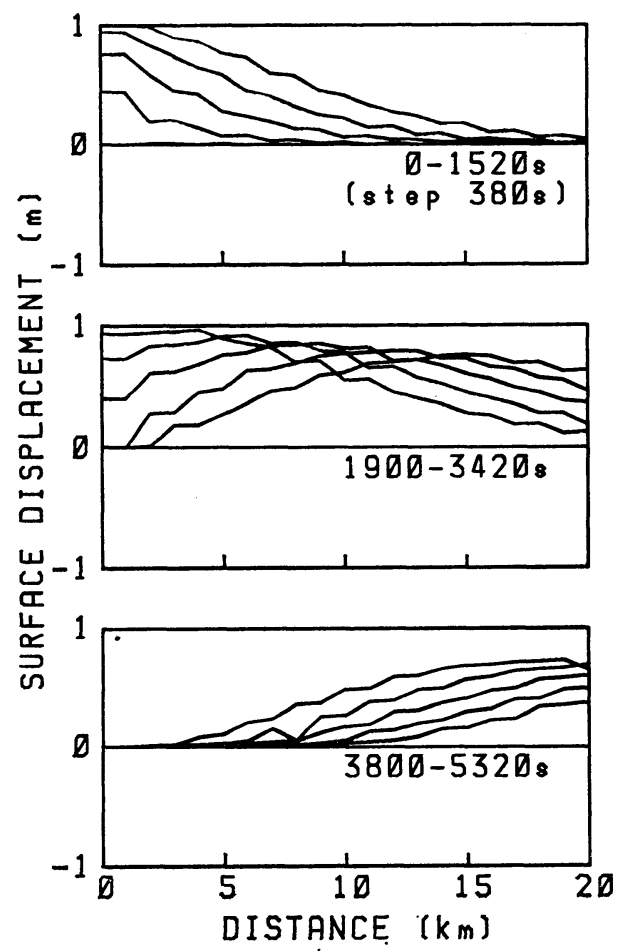

Fig. 8 Flood Wave at Each Time

次に, PAX-128, 汎用大型計算機 FACOM M-200 お よび汎用ミニコンピューター T 1990/20 用いて計算機 ごとの計算時間の比較を行った.

なお, PAX-128 と M-200 とでは浮動小数点演算の 精度に違いがあるために, 連続式と運動方程式からそれ ぞれ得られる, 流量 Q1 と Q2 の誤差の収束を行らル 一プ内における綵り返し数が異なってくる.そこであら かじめ M-200 の繰り返し数を求めておき, それらの值

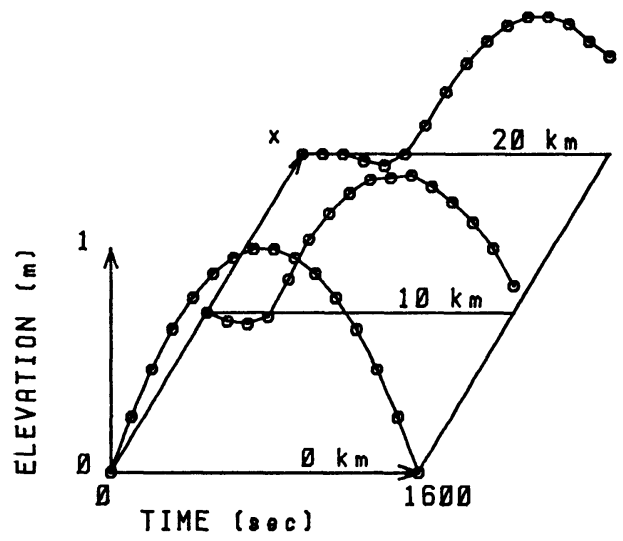

Fig. 9 Flood Wave at Each Point (By PAX-128)

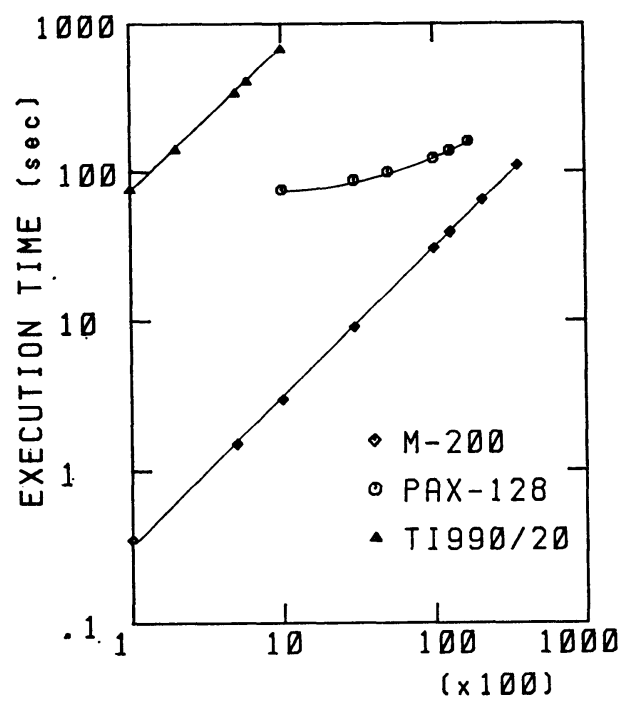

PHYSICAL TIME (sec)

Fig. 10 Comparison of Execution Time

を用いて PAX-128 で計算を行った.

ここで，計算時間とは PAX-128 では並列計算が開始 してから終了するまでとし, HOST からのデータ転送 の時間は含まないものとする.一方，他の計算機で PAX-128 で並列計算を行っている部分に相当する CPU 時間を計算時間と定義する.

物理時間ステップ数を変化させて, 不定流計算を行う のに要した各計算機の計算時間を Fig. 10 に示した.

パイプライン型の計算であるために, 物理時間ステッ プ数が増加するに従い, PAX-128 の並列度が上がり PAX-128 と M-200 の計算時間の差が縮小してくる.

たとえば，物理時間が 5000 秒のときの計算時間は PAX-128 で 99.51 秒, M-200 で 15.12 秒と 6.58 倍 の差があるが，物理時間が 17000 秒になると計算時間 はそれぞれ 160.71 秒, 51.74 秒と PAX-128 の計算時 間は M-200 の 3.11 倍まで接近してくる. 
このように計算速度は, 本研究で行ったパイプライン 型の計算の場合, 計算機の並列度, すなわち, 計算効率 に大きく影響される.

なお, 計算効率 $\alpha$ は存効に並列動作している PUの比 率を表わすもので，この問題において理論的には次式で 与えられる.

$$
\begin{aligned}
& \alpha=\frac{i}{i+p-1} \\
& \text { ここで } \quad i: \text { 物理時間ステップ数 } \\
& p: \mathrm{PU} \text { 台数 }
\end{aligned}
$$

である.

単純にハードウェア性能のみに注目すれば, PAX-128 は効率 $\alpha=1$ のとき, M-200 と同程度の計算速度を持 つと考えられる。したがって式 (11) より，物理時間ス テップ数を増加させれば $\propto$ が 1 に近づくため PAX-128 の計算時間は M-200 の值に漸近していくことが予想さ れる.

しかし， $\alpha=0.9$ の効率を得るためには， $i=1143$ す なわちおよそ 32 時間に及ぶ計算を実施しなければなら ない.

\section{5. 結論}

並列計算機 PAX-128 の水工分野への初めての応用と して，風上差分に工夫をこらした差分スキームを用いて 不定流計算を行った.

その結果, この差分スキームによる比較的安定な解の 得られることが明らかとなった.

またコーディングや言語が計算機により異なるため, PAX-128 と他の計算機の計算速度を単純に 比較するこ とはできないが，本研究で得られた結果では PAX-128 の計算速度は，汎用大型計算機 FACOM M-200 の約 1/3 であった.

この結果を, 計算機のコストも考慮して性能対価格比 の観点からみると以下のようになる.

計算機の価格はシステム構成の仕方により異なって くるが，概算で PAX-128，M-200 の価格をそれぞれ 4000 万円, 22 億円とし, 計算機の性能を計算速度 (計 算時間の逆数) で評価すると，その值は PAX-128 で $1 /$ $160.7=0.006, \mathrm{M}-200$ で $1 / 51.7=0.19$ となる. これら の值を用いて，性能対価格比を計算比較すると， PAX128 の值は M-200の 17 倍となる.

したがって，この值からも PAX-128 がいかに経済的 であるかが理解される．また，性能対価格比の観点から PAX-128 は, 汎用大型計算機を大きく越える能力を持 つものと判断できる.

今後, この特徴を活かし，PAX を計算対象毎の専用
シミュレーターとして利用していくことも考えられる．

\section{謝 辞}

本研究に対して貴重な助言および討議をいただいた筑 波大学講師白川友紀博士, ならびに PAX-128 のプログ ラムの修正改良にご協力いただいた筑波大学技官真島澄 子氏に深甚なる謝意を表する。

また, 本研究には筑波大学大学院生東康夫君が協力さ れた.ここに記して感謝する。

なお, 本研究は昭和 58 年度科学研究費 (58850117) の援 助のもとに行われた。

\section{参考文 献}

1）星野 力・川合敏雄 : スーパーコンピュータ, 科学, Vol. 51, No. 10, pp. 628 635, 1981.

2）星野 力：原子力分野に拈ける超高速技術の応用と展望, 情報処理, Vol. 22, No. 11, pp. 1111 1 118, 1981.

3）星野 力：偏微分方程式解析のためのマイクロプロセッ 苏複合体，情報処理，Vol. 20，No. 11， pp. 974 982， 1979.

4）山岡彰他：科学技術専用並列計算 PACS の開発 (1), 昭 和 55 年度電子通信学会総合全国大会, 6-50。

5）佐藤隆他：科学技術専用並列計算 PACS の開発 (2), 昭 和 55 年度電子通信学会総合全国大会, 6-51.

6) Hoshino, T. et al. : PACS : A parallel microprocessor array for scientific calculations, ACM Transactions on Computer Systems, Vol. 1, No. 3, pp. 195 221, 1983.

7) Hoshino, T. et al. : Highly parallel processing array "PAX" for wide scientific applications, International Conference on Parallel Processing, 1983.

8）星野 力：並列計算機 PACS-32 による BWR 炉心計 算, 日本原子力学会誌, Vol. 23, No. 8, pp. 598 606, 1981.

9）佐藤善行他：PAX-128 による 2 次元弾性体問題の有限要 素解析, 情報处理学会第 28 回全国大会, pp. 119 120.

10) Hoshino, T. et al. : Processing of the molecular dynamics model by the parallel computer PAX, Computer Physics Communication, Vol. 31, pp. 287 296, 1984.

11）関口智嗣他：並列計算機 PAX-128 によるプラズマ粒子 シミュレーション, 情報処理学会第 28 回全国大会, pp. $1309 \sim 1310,1984$.

12）白川友紀他：亚列計算機 PAX-128, 電子通信学会論文詰 1984 年 8 月号揭載予定.

13) Kinoshita, T.: On the motion of the floodflow running down through the river, Proceeding, JSCE, No. 63, pp. $57 \sim 65,1959$.

14) Kinoshita, T.: On the motion of the floodflow running down through the river, Proceeding, JSCE, No. 64, pp. 101 111, 1959.

15) Kikkawa, H. and Shi-igai, H. : On the characteristics of floods at estuary, International Symposium on Floods and Their Computation, 15 22, 1967.

16) Stepién, I.: On the numerical solution of the St Venant equations, Journal of Hydrology, Vol. 67, pp. $1 \sim 11,1984$.

17）建設省土木研究所：陰形式差分法, 土研資料第 1569 号, 昭和 55 年 3 月.

18）建設省土木研究所：河川に抢ける不定流計算法 (II) 一 分合流を考虑した陰形式差分法—, 土研資料 1762 号, 昭和 58 年 3 月. 
19）建設省土木研究所：河川における不定流計算法 (III) 一 複断面を考慮した陰型式差分法一, 土研資料 1939 号, 昭和 58 年 3 月.

20）たとえば, Itoh, T. et al. : Accuracy of the numerical solution for general unsteady river flow equation, IAHR 13th Chngress, 1969.

21）たとえば土木学会: 水理公式集, 昭和 46 年度改訂版.

22）河村哲也：円柱まわりの高レイノルズ数流れの数值計算,
第 15 回流体学講演会講演集, pp. 128〜131, 1983.

23）二村良彦・川合敏雄：PAD によるプログラムの開発 1 , bit, Vol. 12 , No. 4 , pp. $580 \sim 588$.

24）二村良彦・川合敏雄 : PAD によるプログラムの開発 2, bit, Vol. 12, No. 5, pp. 722 729.

25）二村良彦・川合敏雄 : PAD によるプログラムの開発 3, bit, Vol. 12 , No. 6 , pp. $863 \sim 869$.

(1984.6.14 · 受付)

\section{建設基磷工学の綎合コンサルタント}

回営業種目

地質 - 土質調 査・一般測量

室内土質・岩石試験・土木設計

各種物理探査・地盤改良

水

調

査・さく井

登 録

地質調査業

建設コンサルタント

測量業

建

設

業
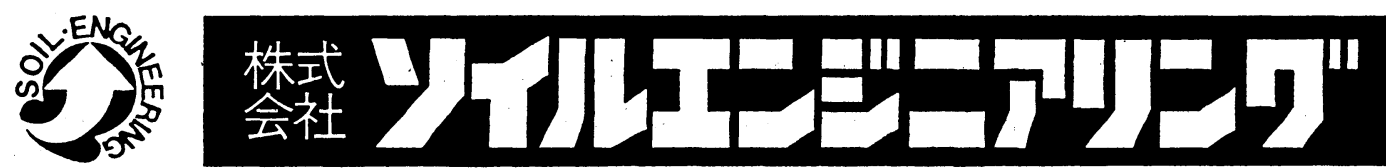

本 社 大阪市浪速区桜川4-8-6(グラスビル)

TEL (06) 568-3585(代)

営業所 東 京・奈 良・京 都・神 戸・松山

試験室 堺 - 浦 和 